\title{
Memorias y Fotografías. Recordando la alfarería en el Río Vaupés. Tesis de Maestría en Historia y Memoria
}

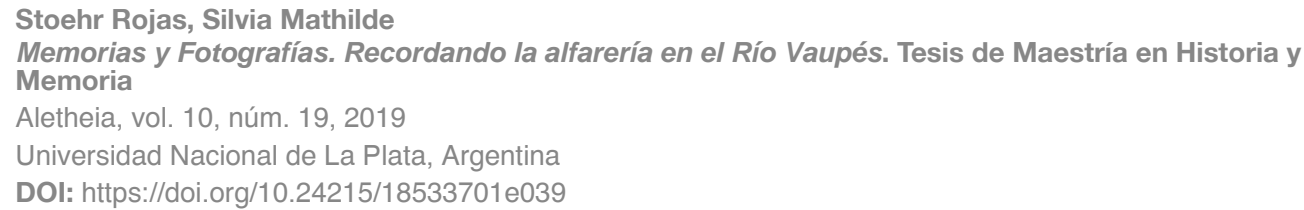

Stoehr Rojas, Silvia Mathilde

Memorias y Fotografías. Recordando la alfarería en el Río Vaupés. Tesis de Maestría en Historia y Memoria

Aletheia, vol. 10, núm. 19, 2019

Universidad Nacional de La Plata, Argentina DOI: https://doi.org/10.24215/18533701e039

Esta obra está bajo una Licencia Creative Commons Atribución-NoComercial-Compartirlgual 4.0 Internacional. 


\section{Memorias y Fotografías. Recordando la alfarería en el Rio Vaupés. Tesis de Maestría en Historia y Memoria}

Silvia Mathilde Stoehr Rojas

DOI: https://doi.org/10.24215/18533701e039

Universidad Nacional de La Plata, Argentina

smstoehrr@unal.edu.com

En el corazón de la Amazonía colombiana nace el río Vaupés, un río de coloración intermedia que lleva su cauce hacia la cuenca del Amazonas. Este territorio sobresale por su diversidad étnica y lingüística, distinguiéndose veinticinco grupos indígenas, que en su adaptación al frágil entorno de la selva húmeda tropical, han desarrollado importantes especializaciones en las artes manuales.

Esta tesis se concentra en una de estas especializaciones: la alfarería, o la producción de piezas en barro cocido (cerámica); analizando los cambios y continuidades de esta práctica cultural a la luz de un trabajo de memoria que utiliza la fotografía como herramienta metodológica para recordar, y a partir de la relación que establecen las personas con las imágenes explora la emergencia de múltiples sentidos del pasado, con el propósito de responder a la pregunta de investigación: ¿Qué relatos construyen las comunidades actuales del Vaupés cuando observan las fotografías relacionadas con la alfarería y con la cerámica?

De modo que esta investigación sigue la propuesta de Jelin (2012: 61) al ser un trabajo que "vincula imágenes y palabras, imágenes de un pasado, y palabras y narraciones ligadas al presente de la memoria estimulada por las imágenes". En este marco, concibe a la fotografía como soporte del recuerdo y como vehículo de memoria, es decir que la analiza como un registro indicial de algo que ocurrió; y al mismo tiempo la comprende como valioso detonador de recuerdos y sensibilidades que diversifican la mirada sobre lo ocurrido.

En este sentido, la tesis es en sí misma, una propuesta metodológica para explorar los alcances y limitaciones de la fotografía etnográfica en la producción de relatos y sentidos del pasado en las comunidades. La propuesta de levantamiento cualitativo tiene un componente fuertemente etnográfico y consiste en la realización de entrevistas abiertas utilizando dos series fotográficas, la primera tomada iniciando el siglo XX por el etnólogo alemán Theodor Koch-Grünberg en su viaje por el Río Negro y el río Vaupés; y la segunda, obra del fotógrafo colombiano Fernando Urbina, tomadas en este afluente amazónico en 1968.

La metodología propuesta resulta novedosa e interesante, el corte etnográfico en la investigación permite una riqueza en detalles paralingüísticos, la kinésica y la proxémica en las entrevista (particularmente las grupales) permite una interpretación de la identificación y el rechazo que sienten los entrevistados frente a las imágenes. De igual manera, el uso de la lengua propia por parte de los entrevistados constituye la configuración de una comunidad afectiva a través de la cual se observa y se transmiten relatos del pasado. Esta propuesta analítica resulta potente para pensar algunos ejes entre fotografía, memoria e identidad y relacionarlos con la genealogía de otras nociones ya consagradas en el campo de estudios sobre memoria.

En la tesis se plantea a la fotografía desde un análisis relacional, pues se concibe a ésta como una relación de relaciones, por lo cual se articula a quien crea la imagen, el objeto (o el sujeto) que aparece y al mismo tiempo a quien la observa y reactualiza (Soulages, 2010). Por ello, este trabajo analiza detalladamente el universo de las fotografías utilizadas en las entrevistas antes de presentar el ejercicio desarrollado; porque estas imágenes en sí mismas y su proceso de producción constituyen parte esencial en el trabajo de memoria. Debido a ello, 
la metodología utilizada no se concentra únicamente en la mirada contemporánea, sino que incluye dentro de su análisis la producción fotográfica y su contexto. Esta postura explica la estructura del texto.

La tesis está dividida en tres capítulos: el primero de ellos constituye una reflexión teórica que justifica y enmarca la metodología que se implementa; el segundo sitúa las fotografías utilizadas; el tercero presenta las entrevistas desarrolladas con las comunidades residentes en el Vaupés. Finalmente la autora expone una serie de consideraciones finales que articulan los argumentos de los tres capítulos; y termina presentado los formatos del levantamiento cualitativo, lo cuales conforman los anexos.

La primera parte de la tesis, titulada La fotografía y las memorias, analiza y justifica el uso de la fotografía como herramienta metodológica de las ciencias sociales para recordar y desde el propio recuerdo de los espectadores (quienes observan las imágenes) analizar esos sentidos del pasado. Siguiendo este enfoque, este capítulo orienta su análisis de la fotografía en dos puntos: i) la fotografía como soporte del recuerdo, lo cual se logra a través de la teoría fotográfica donde se analiza la foto como un huella del acto fotográfico (Dubois, 2002) pero se debate su mimetismo objetivo entendiéndola como una construcción subjetiva que registra un punto de vista de la realidad cognoscible (Fontcuberta, 2002; Sontag, 2006; Soulages, 2010); y ii) la fotografía como vehículo de memoria, reflexión construida a partir de la revisión de diferentes propuestas en las que la foto resulta ser un detonante de discursos y sensibilidades que dan sentido al pasado (Edwards, 2005; 2008; Reyero, 2010; Giordano, 2012; Da Silva, Giordano, Jelin, 2010).

El segundo capítulo de este documento titulado Las memorias reveladas, sitúa a las fotografías, explicando el contexto de producción de las imágenes. Esta investigación utiliza dos series fotográficas: i) veintitrés fotografías relacionadas con la cerámica y la alfarería hechas por el explorador alemán Theodor KochGrünberg en su viaje por el Vaupés y el Río Negro entre 1903-1905 (tomadas de: Koch Grünberg, 1995); ii) dieciséis fotografías de objetos cerámicos hechas por el fotógrafo y filósofo colombiano Fernando Urbina en 1968 en su viaje por el río Vaupés (del archivo personal del fotógrafo, sin publicar). En este segundo capítulo se explora lo que significa hacer fotografías iniciando el siglo XX por un etnólogo alemán, enfatizando en esta tradición académica frente a coleccionismo; en contraste con lo que significa hacer fotografías por un filósofo y fotógrafo colombiano en la década de los sesentas. Estas dos posiciones frente a la producción de imágenes y la relación que exhiben frente al objeto cerámico permite reflexionar sobre la fotografía como un soporte del recuerdo atado a posibilidades y limitaciones técnicas pero también como el registro de un punto de vista de la realidad, condicionado y posicionado por un individuo: el fotógrafo.

Por su parte el tercer capítulo titulado Los relatos frente a las fotografías de la cerámica, detalla los encuentros del ejercicio que aplica la metodología cualitativa propuesta, el cual fue realizado durante el mes de octubre de 2015 con: i) alfareros y alfareras de las comunidades Cubay, y Puerto Golondrina, en el departamento del Vaupés; ii) el grupo femenino del coro de la iglesia; iii) un sabedor tradicional. En este capítulo, se describe la forma en que se desarrollaron las entrevistas, así como las similitudes y diferencias en las respuestas de estos tres grupos al observar las imágenes. En este apartado hay un interés en tres aspectos de la cerámica: i) producción, ii) uso; iii) sentido. Los relatos que detonan las fotografías se articulan en estos tres aspectos, expresando que el objeto de barro no es lo mismo para todos los que lo ven, la identidad atraviesa la mirada sobre las fotografías y es desde esta que se configura una comunidad afectiva desde la que se construye la otredad y el reconocimiento de lo propio. Es a través de la lengua nativa, el gesto y el silencio que se detona una multiplicidad de sentidos sobre una práctica cultural pero también sobre los procesos históricos que han acompañado a las sociedades humanas que residen en la Amazonia colombiana.

Sin duda, la experiencia personal y el bagaje subjetivo de quien observa la imagen es el lineamiento del discurso evocado. La foto aunque sea la misma, ante los ojos del sabedor Enrique Llanos es cultura, pero también es la nostalgia de su infancia; ante las mujeres mayores es la cotidianidad, la gastronomía, el espacio doméstico; frente a los alfareros de Cubay es su medio de vida y al mismo tiempo su legitimidad; frente a las alfareras de Puerto Golondrina es su memoria subterránea que se debe preservar, y su posibilidad de trabajar. 
Las fotografías entonces resultan un vehículo que detona sensibilidades y emociones, recuerdos e historias, que permiten investigar el cambio cultural y los procesos sociales que han acompañado a las comunidades del noroeste amazónico. A través de los relatos, no sólo es posible conocer la relación que entablan actualmente con la alfarería, la mirada y el relato detonado manifiesta disputas frente a los sentidos del pasado, la legitimidad, e incluso frente a los roles sociales. Resulta interesante el uso que dan las comunidades a las fotografías que les son entregadas, actuando como herramientas de las que se apropian para fortalecer una práctica cultural. De igual manera, sobresalen los encuentros de la investigación en cuanto a las implicaciones de la mercantilización en las transformaciones en forma y tamaño de las piezas de barro cocidas.

De igual manera, la tesis propone que las fotografías en estas comunidades tienen un potencial evocativo capaz de detonar discursos sobre imágenes que no están representadas, lo que entrelaza una conversación entre la materialidad y la simbología, las “imágenes mentales" entra en diálogo con las imágenes fotográficas y con los objetos materiales, para hablar de presente y pasado, de cambios y continuidades en la producción, uso y sentido de la alfarería. Debido a ello, la tesis ofrece valiosas reflexiones teóricas sobre la producción y el uso de la fotografía etnográfica en la investigación social y en los trabajos de memoria; habilitando nuevas preguntas acerca de la construcción y reconstrucción de memorias a partir de las imágenes.

\section{REFERENCIAS}

Da Silva Catela, L.; Giordano, M.; Jelin, E. (2010). Fotografía e Identidad. Buenos Aires: Nueva Trilce.

Dubois, Philippe (2002). El acto fotográfico: de la representación a la recepción. Barcelona: Ediciones Paidós Ibérica.

Edwards, Elizabeth (2005). "Photographs and the Sound of History". En Visual Anthropology Review, 21 (1). pp. $27-46$.

Edwards, Elizabeth (2008). Visual sense a cultural reader. Ed. Elizabeth Edwards and Kaushik Bhaumik. Oxford; New York, Berg.

Fontcuberta, Joan (2002). El beso de Judas: fotografía y verdad. Barcelona: Editorial Gustavo Gili.

Giordano, Mariana (2012). Fotografía, testimonio oral y memoria. (Re) presentaciones de indígenas e inmigrantes del Chaco (Argentina). Memoria Americana 20 (2), pp. 295-321.

Jelin, Elizabeth (2012). La fotografía en la investigación social: algunas reflexiones personales. En Memoria y sociedad: revista del Departamento de Historia y Geografia, 16 (33), pp. 55-67

Koch-Grünberg (1995). Dos años entre los indios. Bogotá: Universidad Nacional de Colombia.

Reyero, Alejandra (2010). Ver en fotos, ¿Rever en la memoria?. En Fotografia e Identidad. Buenos Aires: Nueva Trilce. Sontag, Susan (2006). Sobre la fotografía. México: Alfaguara.

Giordan, Mariana y Reyero, Alejandra (2010). La imagen del otro a través del otro. Una experiencia etnográfica con comunidades indígenas chaqueñas y las fotografías de sus antepassados. En Revista Antropología, Historia y Fuentes Orales (40), pp. 149-166.

Reyero, Alejandra (2007). La fotografía etnográfica como soporte o disparador de memoria. Una experiencia de la mirada. En Revista Chilena de Antropología Visual (9), pp. 37-71.

Soulages, François (2010). Estética de la fotografía. Buenos Aires: La Marca.

\section{BY-NC-SA}

\section{INFORMACIÓN ADICIONAL}

Defensa de tesis: 25 de junio de 2019 
Silvia Mathilde Stoehr Rojas. Memorias y Fotografías. Recordando la alfarería en el Río Vaupés. Te...

Directora: Mariana Giordano, Instituto de Investigaciones Geohistóricas, Universidad Nacional del Nordeste/CONICET, Argentina

Codirectora: Ludmila da Silva Catela, Instituto de Antropología de Córdoba, Universidad Nacional de Córdoba/CONICET, Argentina. 